\title{
업무시설 기계실과 전기실의 비상방송설비 음성명료도 Audibility of Emergency Broadcasting Sounds in Mechanical and Electrical Rooms in Office Facilities
}

\author{
정정호* \\ Jeong, Jeong-ho*
}

\begin{abstract}
For the clear presentation of fire warning and emergency broadcasting sounds to occupants of buildings, certain guidelines and requirements have been established. However, the parameters to evaluate the speech intelligibility of the generated sound have not been established. In the NFPA 72 and BS standards, a specific warning sound level for warning sounds in residential facilities is proposed and the speech transmission index (STI) for emergency broadcasting systems is regulated. Mechanical and electrical systems need to be maintained to supply water and electricity in fire and disaster situations. To maintain these functions in buildings, emergency broadcasting sounds need to be clearly delivered to workers in the facilities. For the clear understanding of emergency broadcasting sounds, the background noise in the facilities should be lower than the broadcasting sounds. In addition, broadcasting sounds should not reverberate. In this study, the noise characteristics in the mechanical rooms and electricity facilities of office buildings that were more than 40 years old were measured and used for the acoustic prediction of emergency broadcasting sounds. Audibility and room acoustic properties, such as the reverberation time and STI in the facilities, were simulated by using the room acoustic simulation method. The audibility and STI of emergency broadcasting sounds were evaluated as "bad" or "poor" under the basic conditions. For the clear delivery of emergency broadcast sounds in mechanical and electrical rooms, it is necessary to apply a sound-absorbing material on the walls and ceilings in the facilities to reduce the reverberation. At the same time, an increase in the volume of emergency broadcast sounds and the introduction of additional speakers should be considered.
\end{abstract}

Key words : Emergency Broadcasting System, Speech Transmission Index, Acoustic Simulation, Mechanical and Electrical Room, Sound absorption

\section{요 지}

건물의 거주자에게 화재 경보 및 비상방송음을 명확하게 전달하기 위한 지침과 요구 사항이 수립되어 있으나 비상방송음, 경보음이 얼마나 명료하게 전달되는지에 대한 지표는 부족하다. NFPA 72 및 $\mathrm{BS}$ 표준에서는 주거시설의 경보음에 대한 특정 경보음 수준을 제안하고 비상방송 시스템에 대한 음성전달지수(STI, Speech Transmission Index)를 규정하였다. 기계 및 전기 설비는 화재 및 재난 상황에서 물과 전기 공급하는 중요한 설비이다. 이 기능을 유지하기 위해서는 기계실과 전기실에서 작업자에게 비상방송음을 명확하게 전달하는 것이 시스템의 비상 작동에 매우 중요하다. 기계실과 전기실에서 비상방송음을 명료하게 전달하기 위해서는 비상방송음을 배경소음보다 충분히 크게 전달하고 과다하게 울리지 않아야 한다. 본 연구에서는 40년 이상 된 사옥의 기계실 및 전기시설의 소음특성을 측정하여 음향 시뮬레이션에 반영하였다. 음향 시뮬레이션 방법을 이용하여 여러 조건별 가청도와 음성전달지수(STI)를 예측, 비교하였다. 가청도와 음성전달지수 예측 결과 기본 조건의 기계실과 전기실에서 "Bad", "Poor" 수준이었다. 기계실과 전기실에서 소리가 울리는 것을 방지하기 위해 벽체와 천장에 흡음재를 적용하면 비상방송음을 더 명료하게 전달되는 것으로 나타났다. 이와 함께, 비상방송용 스피커 소리를 크게 하고 추가 스피커를 배치하면 명료한 비상방송음 전달이 가능한 것으로 나타났다.

핵심용어 : 비상방송설비, 음성 전달 지수, 음향 시뮬레이션, 기계실 및 전기실, 흡음

*교신저자, 정회원, 한국화재보험협회 부설 방재시험연구원 수석연구원(Tel: +82-32-887-6737, Fax: +82-31-887-6739, E-mail: jhjeong92@gmail.com) Corresponding Author, Member, Principal Researcher, Fire Safety \& Environment Research Center, Fire Insurers Laboratories of Korea 


\section{1. 서 론}

화재 및 재난이 발생하였을 때 화재와 재난 발생을 신속하 게 감지하고 해당 시설의 거주자와 작업자에서 화재와 재난 발생 상황을 명료하게 전달하는 것이 중요하다. 명료한 화재 및 재난 상황 전파를 위해서는 경보설비와 비상방송설비 (NFSC 202, 2017)가 중요한 역할을 하고 있다. 건물의 거주 자에게 화재 경보 및 비상방송음을 명확하게 전달하기 위한 지침과 요구 사항이 수립되어 있으나 비상 방송음, 경보음이 얼마나 명료하게 전달되는지에 대한 지표는 부족하다. NFPA 72 (2016) 및 BS 8629 (2019) 표준에서는 주거시설의 경보음 에 대한 특정 경보음 수준을 제안하고 비상방송시스템에 대해 음성전달지수(Speech Transmission Index, STI)를 규정 하고 있다(Table 1 참조). Kim et al. (2021)은 다양한 음성명료 도 측정, 평가 지표를 비교하였으며, 그중에서 STI는 주변 소음과 소리의 울림을 모두 고려하고 있으며, 통신, 전기음향 과 건축음향 분야에 모두 표준화되어 활용되고 있는 장점이
있다고 정리하였다. STI 성능으로는 $90 \%$ 이상 구역에서 0.45 이상, 해당 공간의 STI 평균값 0.5 이상을 요구하고 있다. STI 지표는 IEC 60268-16 (2020), IEC 60849 (1998)에 규정되어 있으며, 명료도 등급 등급도 Table 2 와 같이 표준화 되어 있다. Table 2의 Sentence score는 음성학적으로 균형된 단어로 구성된 단문장을 이해하는 정도로 "Fair" 등급 이상에 서는 대부분의 단문장으로 알아들을 수 있는 수준으로 제시 되어 있다.

공동주택 세대 내부로 경보음이 전달되는 정도를 예측과 측정한 결과(Jeong, 2018) 방화문과 세대 내부 방문 등의 영향으로 잘 알아들을 수 없을 것으로 나타났다. 대안으로 각 방에 경보장치 또는 비상방송용 스피커를 설치하고 BS 표준 등과 같이 적절한 경보음 레벨을 설정하는 것을 제안하 였다. 초고층 건축물의 경우 건물 내부 거주자가 동시에 피난하는 경우 병목현상으로 인해 효율적인 피난을 할 수 없다. 이를 예방하기 위해 우선 경보 방식을 적용하여 화재 발생층과 상부층에 먼저 경보를 발생시키는 시스템이 사용

Table 1. Relevant Regulation and Specification on Alarm and Emergency Broadcasting System in NFSC 202, NFPA 72 and IEC 60849

\begin{tabular}{c|l}
\hline NFSC 202 & $\begin{array}{l}\text { 1. The voice input of the loudspeaker must be } 3 \mathrm{~W} \text { (1 W for indoor installation) or more. } \\
\text { 2. Loudspeakers shall be installed on each floor, but the horizontal distance from each part of the floor } \\
\text { to one loudspeaker shall be } 25 \mathrm{~m} \text { or less, and shall be installed so that an alarm can be issued } \\
\text { effectively in each part of the floor. }\end{array}$ \\
\hline NFPA 72 & $\begin{array}{l}\text { D. } 2.4 \text { Acceptability Criteria } \\
\text { D. } 2.4 .1 \text { The intelligibility of an emergency communication system is considered acceptable if at least } \\
90 \text { percent of the measurement locations within each ADS have a measured STI of not less } \\
\text { than 0.45 (0.65 CIS) and an average STI of not less than 0.50 STI (0.70 CIS). }\end{array}$ \\
\hline IEC & $\begin{array}{l}\text { Annex A, A.3 Limitations of of the methods } \\
\text { A.3.2 Speech transmission index (STI) } \\
\text { b) the total harmonic distortion of a sinusoidal signal giving the same sound pressure level at the } \\
\text { measuring position ad the STI test signal does not exceed } 17 \% \text { (corresponding to approximately } 1 \mathrm{~dB} \\
\text { of compression of a pink-noise signal due to the peak slipping) } \\
\text { Annex C } \\
\text { C.2 Audibility of attention drawing signals } \\
\text { Attention drawing signals over the whole an area of coverage should meet the following criteria: } \\
\text { a) absolute minimum sound level : } 65 \mathrm{dBA} \\
\text { b) absolute minimum sound level in sleeping mode : } 75 \mathrm{dBA} \\
\text { c) alarm sound audibility over background noise : } 6 \mathrm{dBA} \text { to } 20 \mathrm{dBA} \text { (or } 9 \mathrm{~dB} \text { to } 23 \mathrm{~dB} \text { in relevant } \\
\text { alarm frequency bands) } \\
\text { d) maximum alarm sound level (to limit exposure) : } 120 \mathrm{dBA}\end{array}$ \\
\hline
\end{tabular}

Table 2. STI Rating (IEC 60286-16)

\begin{tabular}{c|c|c}
\hline Intelligibility rating & STI & Sentence score \\
\hline Excellent & $>0.75$ & $100 \%$ \\
\hline Good & $0.60 \sim 0.75$ & $100 \%$ \\
\hline Fair & $0.45 \sim 0.60$ & $100 \%$ \\
\hline Poor & $0.30 \sim 0.45$ & $70 \% \sim 100 \%$ \\
\hline Bad & $<030$ & $<70 \%$ \\
\hline
\end{tabular}


되고 있다. 그러나, 경보 발생 층뿐만 아니라 엘리베이터 샤프트(Jeong, 2019)와 피난계단(Jeong, 2021)을 통해 아래 층과 위층으로 경보음이 전달되어 우선 경보 시스템의 목적 을 달성하기 어려운 것으로 나타났다. 주거 공간과 함께 건축물 내부의 여러 가지 작업자들도 작업 공간의 소음 발생 등으로 경보음 또는 비상방송을 알아듣기 어려울 수 있다. Jeong (2020a)은 전산 서버실을 대상으로 서버실 소음 을 측정하고 음성명료도를 예측한 결과 작업자들이 경보음 을 명확하게 알아듣기 어려운 정도라고 보고하였다.

화재 및 재난 상황에서 중요한 시설은 급수 설비와 수변전 설비이다. 건물에서 급수와 전기 설비를 유지하기 위해서는 기계실과 전기실에서 작업자에게 비상방송음을 명확하게 전달하는 것이 시스템의 비상 작동에 매우 중요하다. 이에 본 연구에서는 기계실과 전기실 작업자가 여러 건축설비와 소방설비를 비상 운용하는 데 도움을 주고, 유사시에는 신속 하게 피난할 수 있게 하려고 기계실과 전기실에서 발생하는 소음과 소리 울림 등을 고려하여 경보 및 비상방송이 명료하 게 전달하는 방안을 연구하였다. 이를 위해, 40 년 이상 된 사옥의 기계실 및 전기실의 소음도를 측정하였다. 기계실과 전기실의 소음측정 결과는 비상방송음 전달 예측의 입력값 으로 활용하였다. 기계실과 전기실의 비상방송음 전달 예측 은 국제표준(EN 12354-6, 2004)을 바탕으로 한 건축음향 예측 프로그램(Odeon-Ver.12)을 사용하여 각 예측 조건별 잔향시간, 비상방송음의 STI를 예측, 비교하였다.

건축음향 예측 프로그램은 $3 \mathrm{D}$ 공간을 모델링하고, 각 구성면의 흡음성능과 배경소음측정 결과를 입력하고 음원 (스피커)에서 발생하는 소리 크기와 지향성 등을 설정하여 STI 등 음성명료도 지표와 다양한 실내음향 지표를 예측할 수 있다. 해당 예측 프로그램은 공연장의 음향 설계, 다양한 산업 공간의 소음 레벨 예측 등에 널리 사용되고 있으며, 소리의 확산 전달 현상은 정확하게 예측하는 데에는 한계가 있다.

\section{2. 설비 소음측정}

사무용 건물 기계실과 전기실에서의 비상방송음의 명료 도 평가를 위해 기계실과 전기실 내부의 소음 발생 특성을 측정하였다. 측정 대상 사무용 건물은 서울특별시 여의도에 있는 건물로 1970 년대 건설된 지상 15 층, 지하 2 층 규모로 주기적인 설비 유지 보수가 이루어졌다. 주요 기계 설비로는 냉동기, 급탕, 급배수, 환기 설비 등이 기계실에 설치되었다. 전기실에는 수변전 설비가 별도의 공간으로 설치되어 있었다.

소음측정은 냉방 설비와 냉동기가 가동되는 여름철에 실시하였다. 설비 소음측정은 주요 설비가 설치된 기계실, 전기실과 부속 공간인 펌프실, 엘리베이터 권상기실을 대상 으로 하였다. 소음측정은 Fig. 1과 같이 KS C IEC 61672-1 표준의 등급 2 성능을 만족하고 $1 / 3$ 옥타브 대역 실시간

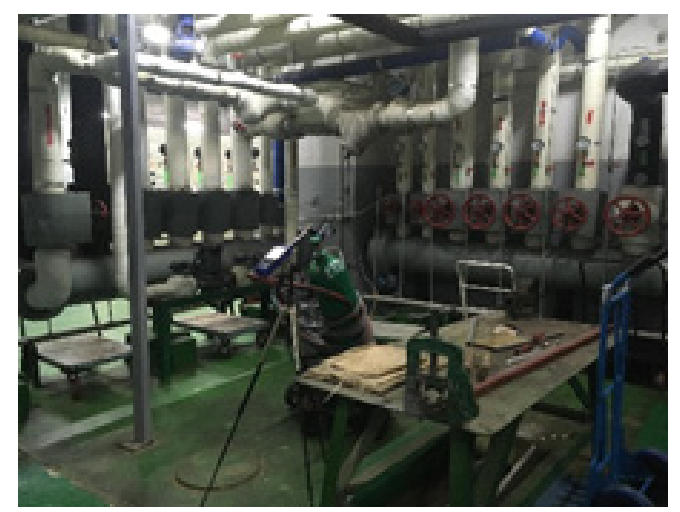

(a) Mechanical room

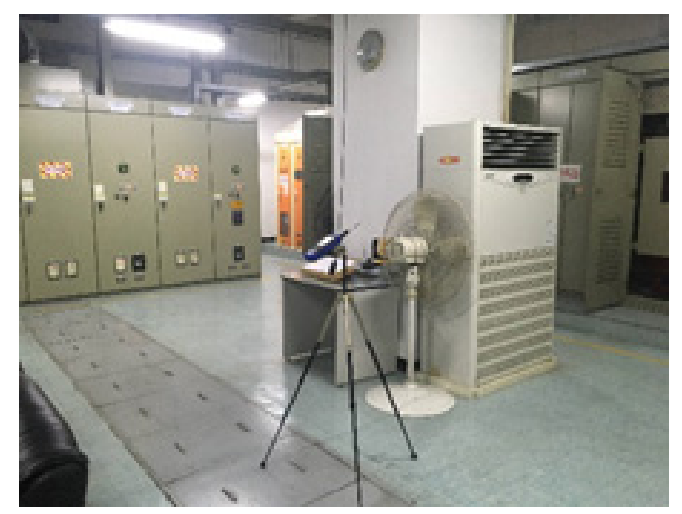

(b) Electrical room

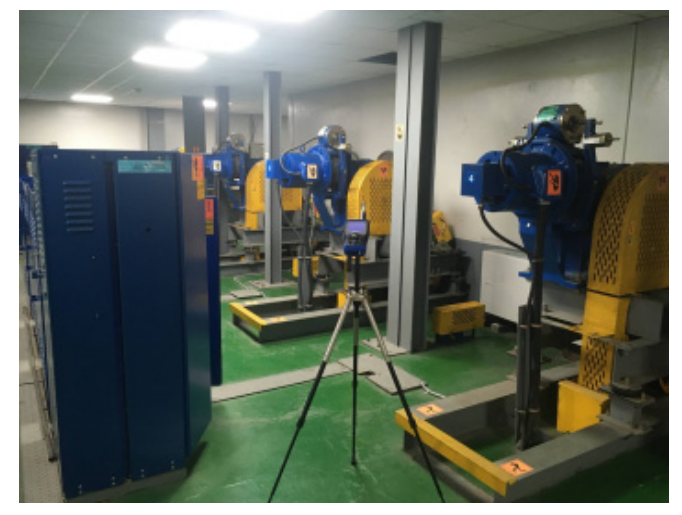

(c) Noise level Elevator traction machine room

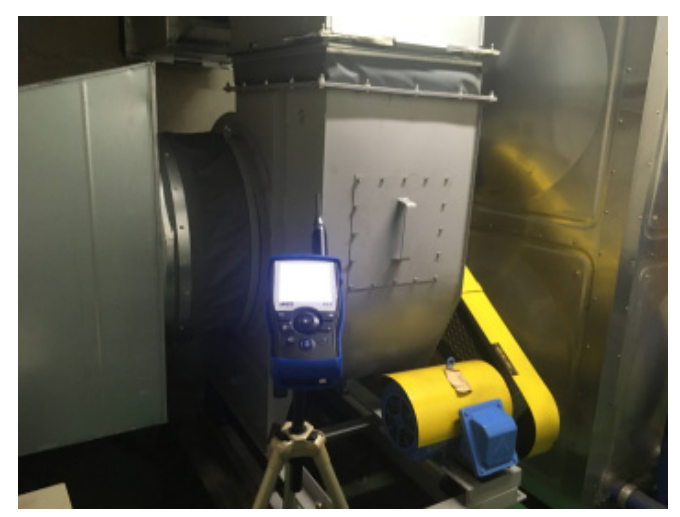

(d) Exhaust fan room

Fig. 1. Noise Level Measurement in the Mechanical and Electrical Room of Office Building 
주파수 분석이 가능한 소음계(NTi XL2)를 사용하여 바닥 표면으로부터 $1.2 \mathrm{~m}$ 높이에서 측정하였다.

기계실과 전기실의 천장 및 벽면은 시멘트 미장 마감에 페인트 색칠된 상태로 별로의 흡음재가 적용되지 않았으며, 바닥 면은 에폭시 마감과 플라스틱 타일로 마감되었다. 기계 실과 전기실에 별도의 흡음재료가 적용되지는 않은 상태였 다. 냉동기의 경우 발생하는 소음을 차단하기 위한 방음 시설이 추가로 설치되었다.

기계실의 소음측정 지점은 주요 설비의 부근으로 선정하 였다. 기계실의 소음측정 위치는 배기팬, 배기팬과 냉동기 사이, 급수 펌프와 분배기 위치와 냉각수 펌프 부근으로 선정하였다. 주요 기계장치 소음측정 결과는 옥타브 대역으 로 정리하여 Fig. 2에 정리하였다. Fig. 2와 같이 상대적으로 저주파수 대역으로 갈수록 음압레벨이 증가하는 특성을

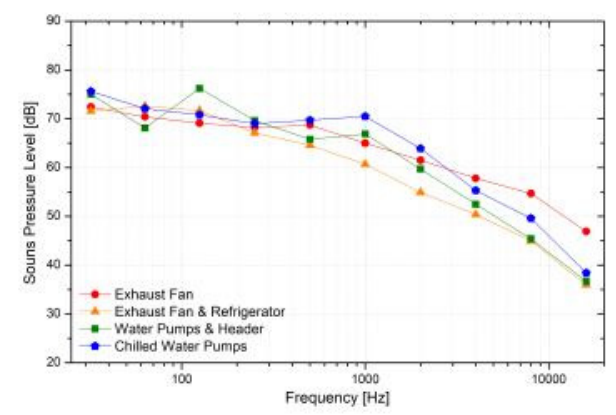

(a) Frequency characteristics of noise in mechanical room

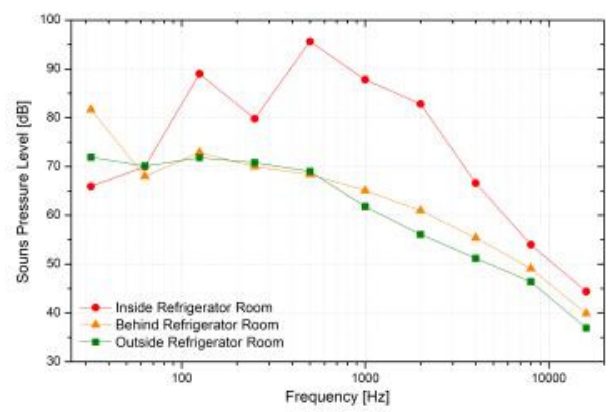

(b) Refrigerator room

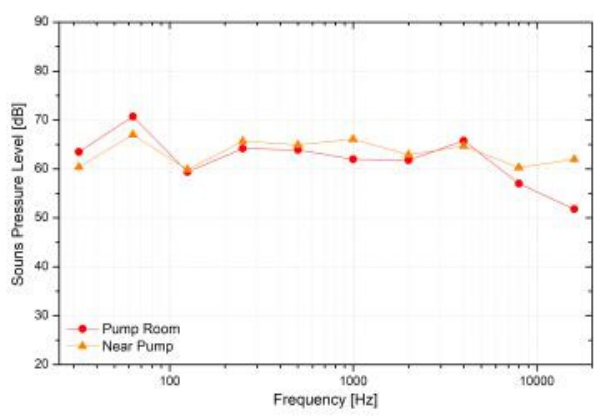

(c) Pump room

Fig. 2. Noise Level Measurement Results in the Mechanical Rooms
갖는 것으로 나타났으며, 배기 팬의 소음 특성이 가장 평탄한 주파수 특성을 갖는 것으로 나타났다.

급수 펌프와 냉각수 펌프는 Fig. 2(a)와 같이 $125 \mathrm{~Hz}$, $1 \mathrm{kHz}$ 대역에서 상대적으로 높은 것으로 측정되었다. Fig. 2(b)는 냉동기에 설치된 방음 시설 주변과 냉동기에 근접한 방음 시설 내부의 소음측정 결과이다. 냉동기가 설치된 방음 시설 주변의 소음 특성은 Fig. 2(a)의 배기팬과 냉동기 소음 특성과 유사하였으며, 이는 냉동기 소음과 주변 설비 기구의 소음 특성이 함께 반영된 결과로 판단된다. 냉동기의 방음시 설 내부 소음은 약 $94.7 \mathrm{~dB}(\mathrm{~A})$ 로 $125 \mathrm{~Hz}$ 와 $1,600 \mathrm{~Hz}$ 대역에서 상대적으로 음압레벨이 높은 특성을 갖는 것으로 나타났다.

배수펌프가 설치된 펌프실의 소음측정 결과는 Fig. 2(c)와 같다. 펌프실의 소음은 기계실 소음보다는 음압레벨이 상대 적으로 낮지만, 전체 주파수 대역에서 평탄한 주파수 특성을 갖는 것으로 나타났다. Fig. 3 은 전기실의 소음측정 결과이다. 전기실 소음은 Fig. 3(a)와 같이 기계실 소음보다 음압레벨이 낮게 나타났으며, 수·변전 장치의 특성으로 인해 $16 \mathrm{kHz}$ 대역 레벨이 상대적으로 높게 나타났다.

Fig. 3(b)는 엘리베이터 권상기와 배기 팬 실의 소음 특성을 나타낸 것이다. 엘리베이터실 권상기 실에는 6대의 권상기 가 설치되어 있었으며, 내부 천장은 흡음텍스, 벽체는 페인트 마감 그리고 바닥은 에폭시 도장으로 마감되어 있었다. 엘리 베이터 권상기 실의 소음은 권상기에서 약 $1 \mathrm{~m}$ 정도 떨어진 위치에서 측정하였으며, 권상기 실의 입구부, 중앙부와 끝부

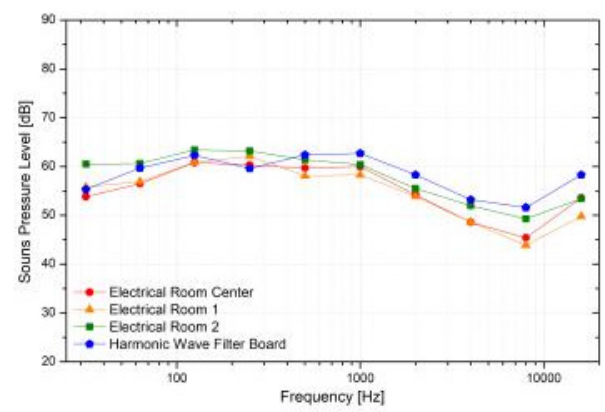

(a) Electrical room

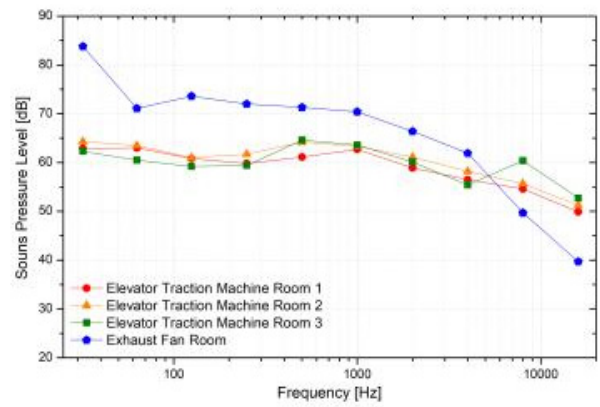

(a) Elevator traction machine room

Fig. 3. Noise Level Measurement Results in the Electrical, Elevator Traction Machine and Exhaust Fan Room 
분의 3 지점에서 각 3 회 측정하여 평균하였다. 엘리베이터 권상기 실의 소음 특성과 레벨은 전기실의 특성과 유사하였 지만, 권상기 구동부의 마찰 소음 등으로 인해 $2 \mathrm{kHz} 8 \mathrm{kHz}$ 대역의 레벨이 상대적으로 크게 나타났다. 배기팬은 해당 업무시설의 위생설비 배기를 위한 설비로 최상부 부분에 별도의 실로 구획되어 있었으며, 배기팬 실 문을 개방하고 배기팬에서 약 $1 \mathrm{~m}$ 떨어진 위치에서 3회 측정하여 평균하였 다. 배기팬 실의 소음은 Fig. 2 의 기계실 소음 특성과 유사한 특성을 갖는 것으로 나타났다. 배기팬의 주요 소음 발생 부위는 팬과 모터였으며, 기계실에 설치된 급배수 펌프 구동 과 냉동기 등 냉방설비 구동을 위한 팬과 모터에서 주로 소음이 발생하기 때문에 유사한 주파수 특성을 갖는 것으로 판단된다.

기계실과 전기실 등에서 발생하는 소음측정 결과 설비 기계가 설치된 공간의 소음 특성은 저주파수 대역 레벨이 $70 \mathrm{~dB}$ 이상 수준이며 주파수 대역이 증가함에 따라 레벨은 낮아지는 특성 나타냈으며, 전기실, 모터 등이 주로 사용되는 설비기기의 경우 $1 \mathrm{kHz}$ 이하 대역의 레벨은 약 $60 \mathrm{~dB}$ 수준으 로 평탄하게 나타났다. 위 소음측정 결과를 기계실과 전기실 의 비상방송음의 음성전달지수를 예측할 때 배경 소음의 입력값으로 활용하였다.

\section{3. 시뮬레이션을 통한 기계실과 전기실의 비상방송설비 음성명료도 분석}

\section{1 시뮬레이션 개요 및 방법}

사무용 건물의 기계실과 전기실에서 비상방송음과 경보 음이 명료하게 전달되어 해당 공간에서 일하는 작업자가 화재 및 재난 발생할 때 적절하게 정보를 전달받고 조처를

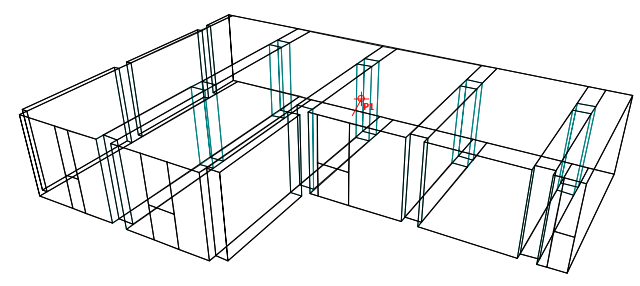

(a) Installed speaker position (As Is)

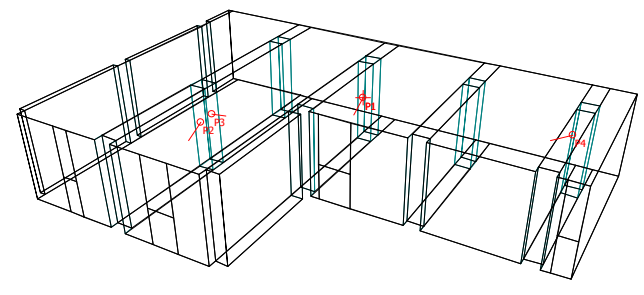

(b) 3 speakers added

Fig. 4. 3D Model of Mechanical Room and Emergency Broadcasting Speaker Position
할 수 있을지를 실내 음향 시뮬레이션을 통해 예측하였다. 대상 기계실과 전기실의 기초 상태를 비교하기 위하여 Figs. 4,5 와 같이 건축 공간만을 모형화하여 비교하였다. 기계실과 전기실에는 비상방송용 스피커가 1 개소에만 설치되어 있어 건축음향 시뮬레이션의 음원 위치로 설정하였다. 기계실의 크기는 $25.7 \mathrm{~m} \times 17.2 \mathrm{~m}$, 전기실은 $14.6 \mathrm{~m} \times 12.1 \mathrm{~m}$ 크기였으 며, 기계실과 전기실의 높이는 $5 \mathrm{~m}$ 로 하였다. 기계실과 전기 실의 표면 마감은 콘크리트 또는 시멘트 마감 면에 페인트 도장이 되어 있었다.

비상방송용 스피커 설정은 기계실과 전기실에 스피커가 설치된 위치로 설정하였다. 스피커의 지향 특성으로는 반구 형태로 소리가 발생하도록 설정하였다. 스피커 종류별로 지향성과 주파수 특성이 다르게 나타나지만, 본 예측에서는 스피커 종류와 지향성 특성 자료를 확인할 수 없어 반구 형태로 설정하여 비교하였다. 향후 비상방송용 스피커의 지향성, 주파수 응답 특성과 음향 출력 등에 대한 데이터베이 스 구축이 필요하다.

음성명료도 예측 지표로는 Speech Transmission Index (STI) 를 비교하였다. STI 비교는 기계실과 전기실에서 발생하는 소음을 고려하지 않은 상태와 각 공간의 소음 발생 측정 결과를 입력하여 예측한 결과를 비교하였다. 이와 함께 기계 실과 전기실 벽면에 흡음재료를 적용하였을 때 STI 변화를 함께 비교하였다.

NFPA 72 National Fire Alarm Signaling Code에는 STI 0.5 이상을 음성명료도 기준으로 제시하고 있다. 기계실과 전기실의 음성전달지수 공간 평균을 위해서는 $3 \mathrm{~m}$ 간격의 격자를 설정하고 각 격자에서의 예측값을 평균하였다. 기계 실과 전기실의 음성전달지수 예측 결과의 평균값은 각각 Tables 2와 3 과 같다.

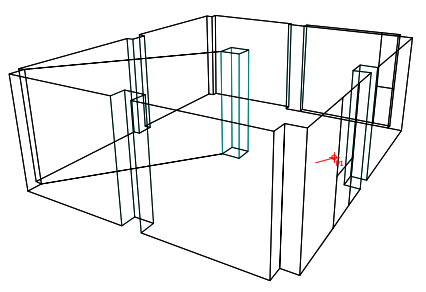

(a) Installed speaker position (As Is)

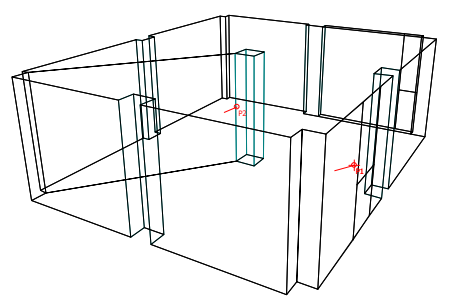

(b) 1 speakers added

Fig. 5. 3D Model of Electrical Room and Emergency Broadcasting Speaker Position 
Table 3. Averaged STI Values and Ratings in the Mechanical Room of the Office Building

\begin{tabular}{l|c|c}
\hline \multicolumn{1}{c|}{ Case } & $\begin{array}{c}\mathrm{STI} \\
(\mathrm{Rating})\end{array}$ & $\begin{array}{c}\mathrm{RT}_{1 \mathrm{kHz}} \\
{[\mathrm{s}]}\end{array}$ \\
\hline 1. Basic condition & $\begin{array}{c}0.27 \\
(\mathrm{Bad})\end{array}$ & 8.28 \\
\hline 2. Noise measurement results applied & $\begin{array}{c}0.18 \\
(\mathrm{Bad})\end{array}$ & 8.28 \\
\hline 3. Case $2+$ Wall absorber applied & $\begin{array}{c}0.29 \\
(\mathrm{Bad})\end{array}$ & 1.96 \\
\hline $\begin{array}{l}\text { 4. Case } 3+\text { Ceiling absorber applied } \\
\text { increased }\end{array}$ & $\begin{array}{c}0.31 \\
(\text { Poor })\end{array}$ & 0.47 \\
\hline 5. Case $4+$ Speaker level 10 dB & $\begin{array}{c}0.42 \\
(\text { Poor })\end{array}$ & 0.47 \\
\hline 6. Case $4+$ Speaker level 20 dB & $\begin{array}{c}\mathbf{0 . 5 6} \\
\text { (Fair) }\end{array}$ & $\mathbf{0 . 4 7}$ \\
\hline 7. Case $5+3$ speakers added & $\begin{array}{c}\mathbf{0 . 5 0} \\
\text { (Fair) }\end{array}$ & $\mathbf{0 . 4 5}$ \\
\hline 8. Case 6 + 3 speakers added & $\begin{array}{c}\mathbf{0 . 6 5} \\
\text { (Good) }\end{array}$ & $\mathbf{0 . 4 5}$ \\
\hline
\end{tabular}

\section{2 기계실의 음성명료도 결과}

기계실에서 발생하는 소음 특성을 반영하지 않은 경우 (Case 1)의 STI 평균치는 Table 3에서와 같이 0.27로 STI 0.30 이하인 "Bad" 수준에 해당하였다. 기계실에서 발생하는 각종 설비 소음의 평균 특성을 고려(Case 2)하여 STI를 예측 한 결과 평균값은 0.20 으로 역시 "Bad" 등급에 해당하였다.

STI는 비상방송용 스피커에서 발생한 소리가 왜곡되는 정도를 평가하는 지표로 소리가 왜곡되는 원인으로는 해당 공간의 소리 울림과 주변 소음이 있다. 소리 울림을 줄이기 위해서는 흡음재를 사용하여 해당 공간에서 소리가 빨리 흡수되도록 하는 방안이 있으며, 소음 레벨로 인한 STI 저하 는 해당 공간의 소음 발생을 줄이거나 비상방송음의 크기를 더 크게 하는 방법이 있다. 본 연구에서는 단계적으로 소리 울림을 제거하기 위해 흡음재료를 적용하는 방안과 비상방 송음을 더 크게 발생시키기 위해 스피커 출력과 개수를 증가하는 방안을 예측하여 비교하였다.

기계실의 경우 각종 설비에서 발생하는 소음이 공간 안에 서 울려 더 커지는 것을 방지하기 위해 벽면과 천장에 흡음재 를 적용하기도 한다. 이를 고려하여 벽면(Case 3)과 천장면 (Case 4)에 단계적으로 미네랄울 흡음재를 적용하고 설비 소음측정 결과를 반영하여 STI를 예측하였다. 흡음재를 벽 면과 천장에 각각 적용한 결과 STI 평균값이 $0.29,0.31$ 로 흡음재 적용에 따라 STI 평균값이 증가하였으나, 설비기기 에서 발생하는 소음으로 인해 STI 평가는 "Bad" 수준이었다. 소리 울림을 제어하기 위해 흡음재 적용만으로 STI 0.5 를 달성하기 어려워, 기계실에 설치된 스피커에서 발생하는

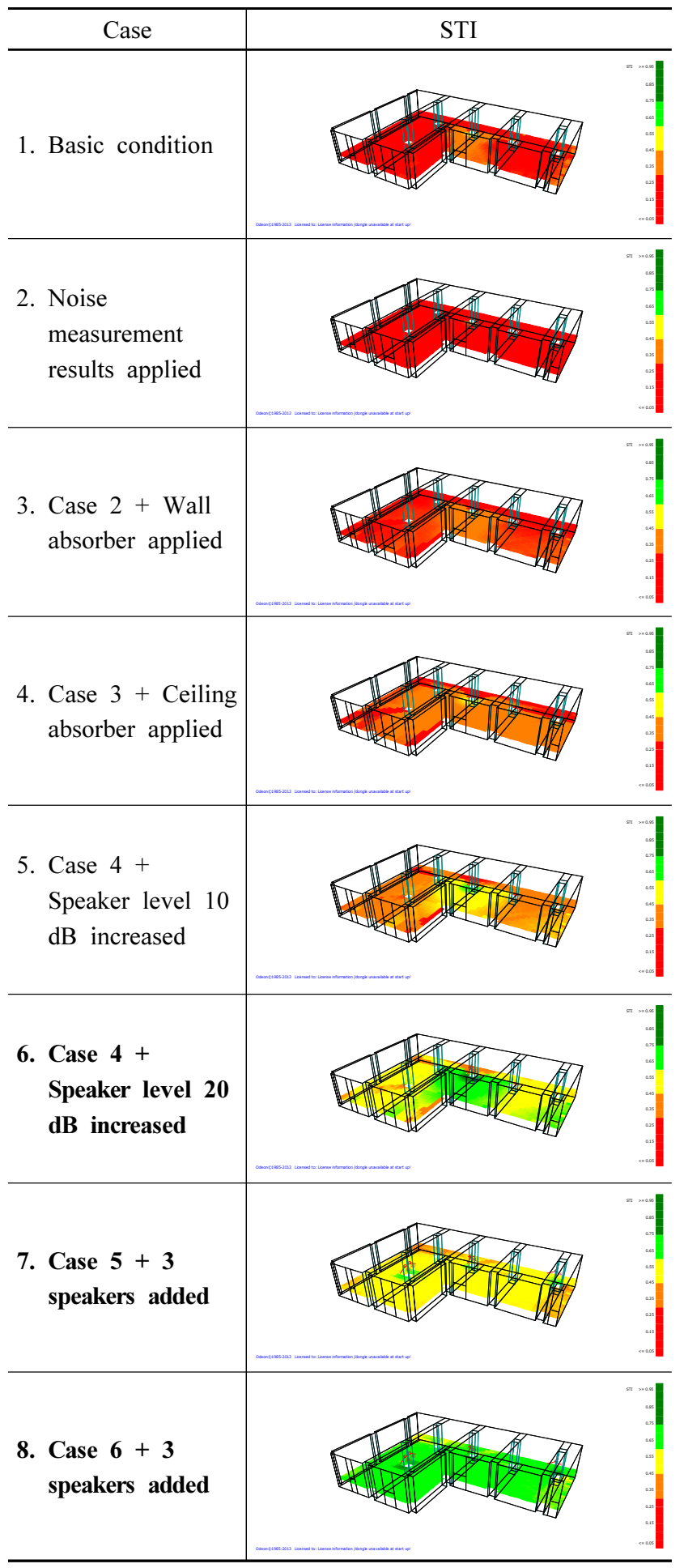

Fig. 6. STI Distribution in the Mechanical Room

소리 크기를 $10 \mathrm{~dB}, 20 \mathrm{~dB}$ 더 크게 발생시키는 방안과 스피커 를 여러 개 설치하는 방안을 조합하여 검토하였다. 기계실에 설치된 비상방송용에서 발생하는 소리를 $10 \mathrm{~dB}$ 크게 한 결과(Case 5) STI 평균값이 0.42로 증가하였지만, NFPA 72 의 기준은 만족하지 못하는 것으로 나타났다. 비상방송용 
스피커의 출력을 $20 \mathrm{~dB}$ 증가한 결과 기계실의 STI 평균값이 0.56 으로 NFPA 72 의 기준을 만족한 수준으로 향상되었다. 스피커의 출력을 증가시키는 방안과 함께 여러 개의 스피커 를 설치한 경우(Case 7,8)에 대해서 추가로 검토하였다. 기계실의 경우 스피커 3 개를 추가하였으며, 기계실 공간 안에서 비상방송음이 고르게 분포하도록 위치를 선정하였 다(Fig. 4(b) 참조).

스피커 출력을 $10 \mathrm{~dB}$ 증가시키고 추가 스피커를 3 개 적용한 결과 STI 평균값은 0.5 로 NFPA 72의 기준을 만족하 였으며, 스피커 소리를 $20 \mathrm{~dB}$ 크게 하고 스피커를 추가한 경우에는 STI 평균값이 0.65 로 향상되어 "Good" 등급에 해당하였다(Table 3 참조).

Fig. 6은 조건별 기계실의 STI 분포 결과를 정리한 것이다. Fig. 6의 그림은 Table 1의 STI 등급을 색깔로 구분하여 표시하도록 설정하였다. 기계실에서 발생하는 소음을 고려 하지 않은 기본 조건(Case 1)의 경우 비상방송용 스피커가 설치된 위치 주변 일부만 "Poor" 수준으로 나타났다. 기계실 에서 발생하는 소음을 고려하여 예측한 결과(Case 2), 기계실 전체 공간에서 STI가 "Bad" 수준이었으나, 소리의 울림을 줄이기 위해 적용한 흡음재가 벽면과 천장에 각각 적용한 결과 Case 4와 Case 5에서와같이 "Poor" 등급에 해당하는 공간이 넓어졌다. 그러나, 흡음재의 적용만으로 STI를 "Fair" 등급 이상으로 향상되지는 않았다.

비상방송용 스피커에서 발생하는 소리 크기를 $10 \mathrm{~dB}$, $20 \mathrm{~dB}$ 크기하고 기계실의 공간 크기와 형상을 고려하여 3개의 스피커를 추가로 설정하여 STI 분포를 예측하였다. 비상방 송용 스피커의 소리 크기를 $10 \mathrm{~dB}$ 크게 한 결과(Case 5) 비상방송용 스피커 주변 공간에서 "Fair" 이상 등급으로 STI 가 향상되었다. 소리 크기를 $20 \mathrm{~dB}$ 크게(Case 6) 하면 기계실 의 일부 공간을 제외하고는 대부분 STI가 "Fair" 등급 이상이 었다. Case 7은 스피커에서 발생하는 소리 크기를 $10 \mathrm{~dB}$ 크게 하고 3 개의 스피커를 추가로 배치하여 예측한 결과로, 기계실 대부분 공간에서 "Fair" 수준으로 STI가 항상되었다. 비상방송용 스피커의 소리 크기를 $20 \mathrm{~dB}$ 크게 하고 3 개 스피커를 추가 배치한 결과 기계실 대부분 공간에서 "Good" 성능을 만족하였다. 기계실과 같이 소음이 발생하는 공간의 경우 STI 기준을 만족하기 위해서는 흡음재 적용, 비상방송 용 스피커의 소리를 더 크게 하고 스피커를 추가로 배치하는 등의 방법을 고려할 수 있다.

\section{3 전기실의 음성명료도 결과}

전기실에서의 소음 수준은 기계실보다 주파수 대역별로 약 $5 \mathrm{~dB} 10 \mathrm{~dB}$ 정도 낮았다(Figs. 2, 3 참조). 전기실의 비상방 송음 STI 예측 결과 전기실 공간의 소리 울림만(Case 1)을 고려하여 예측한 결과 Table 3에서와같이 STI 평균값은 0.27 로 기계실과 유사한 수준이었다. 전기실에도 소리를 흡 수하는 흡음재가 적용되지 않은 "Bad" 등급에 해당하였다.
전기실에서 발생하는 소음 특성(Fig. 3 참조)을 반영(Case 2)하 여 STI를 예측한 결과 STI 평균값은 0.22 로 기계실보다는 다소 높게 나타났는데, 이는 기계실에서 발생하는 소음보다 전기실에서 발생하는 소음 레벨이 작고 전기실의 용적이 기계실보다 작아 소리 울림이 덜하기 때문으로 판단된다. 전기실의 벽면(Case 3)과 천장 면(Case 4)에 각각 흡음재를 적용하였을 때 STI 평균치는 각각 $0.40,0.47$ 로 벽면에 흡음재 를 적용한 경우는 "Poor", 벽면과 천장 모두에 흡음재를 적용한 경우는 "Fair" 수준에 해당하였다. 흡음재를 벽면과 천정에 적용하여 음성전달지수가 개선되었으나 NFPA 72에 제시된 0.50 보다는 낮았다. 전기실에서도 흡음재를 적용하 여 공간 안의 소리 울림을 줄여주는 것만으로 기준을 만족하 지는 못하였다.

전기실에서 STI 기준을 만족시키는 방안을 찾기 위하여 스피커에서 발생하는 소리 크기를 $10 \mathrm{~dB}$ 크게 설정(Case 5)하 여 예측하였다. 스피커에서 발생하는 소리를 크게 한 결과 STI 평균값이 0.63 으로 "Good” 등급으로 NFPA 72의 기준치 를 상회하는 것으로 나타났다. Case 6은 스피커 소리 크기를 증가시키지 않은 상태에서 한 개의 스피커를 추가로 적용 (Fig. 5 참조)하여 예측하였다. 스피커를 추가로 적용함에 따라 비상방송음이 충분한 크기로 전달되지 않는 영역이 크게 줄어들어서 STI 평균값이 0.51로 나타났다. Case 7은 스피커에서 발생하는 소리 크기를 $10 \mathrm{~dB}$ 증가시키고 추가 스피커를 배치한 설정으로 예측하였다. 스피커 소리 크기를 크게 하고 추가 스피커를 적용한 결과 STI 평균값은 0.67 로 증가하였으며, "Good" 등급에 해당하는 것으로 나타났다.

Table 4는 전기실의 STI 분포를 비교한 것이다. 기본조건 의 경우 방송용 스피커 주변의 일부 구역은 일부 “Poor"에 해당하는 수준이었으나, 기계실과 전기실의 소음 발생 특성

Table 4. Averaged STI Values and Ratings in the Electrical Room of the Office Building

\begin{tabular}{l|c|c}
\hline \multicolumn{1}{c|}{ Case } & $\begin{array}{c}\mathrm{STI} \\
(\text { Rating })\end{array}$ & $\begin{array}{c}\mathrm{RT}_{1 \mathrm{kHz}} \\
{[\mathrm{s}]}\end{array}$ \\
\hline 1. Basic condition & $\begin{array}{c}0.27 \\
(\mathrm{Bad})\end{array}$ & 8.40 \\
\hline 2. Noise measurement results applied & $\begin{array}{c}0.22 \\
(\mathrm{Bad})\end{array}$ & 8.40 \\
\hline 3. Case 2+ Wall absorber applied & $\begin{array}{c}0.40 \\
(\text { Poor })\end{array}$ & 2.19 \\
\hline 4. Case 3 + Ceiling absorber applied & $\begin{array}{c}0.47 \\
(\text { Fair })\end{array}$ & 0.33 \\
\hline 5. Case 4 + Speaker level 10 dB & $\begin{array}{c}\mathbf{0 . 6 3} \\
\text { increased }\end{array}$ & $\mathbf{0 . 3 3}$ \\
\hline 6. Case 4 + speaker added & $\begin{array}{c}\mathbf{0 . 5 1} \\
\text { (Fair) }\end{array}$ & $\mathbf{0 . 3 3}$ \\
\hline 7. Case 5 + speaker added & $\begin{array}{c}\mathbf{0 . 6 7} \\
\text { (Good) }\end{array}$ & $\mathbf{0 . 3 3}$ \\
\hline
\end{tabular}




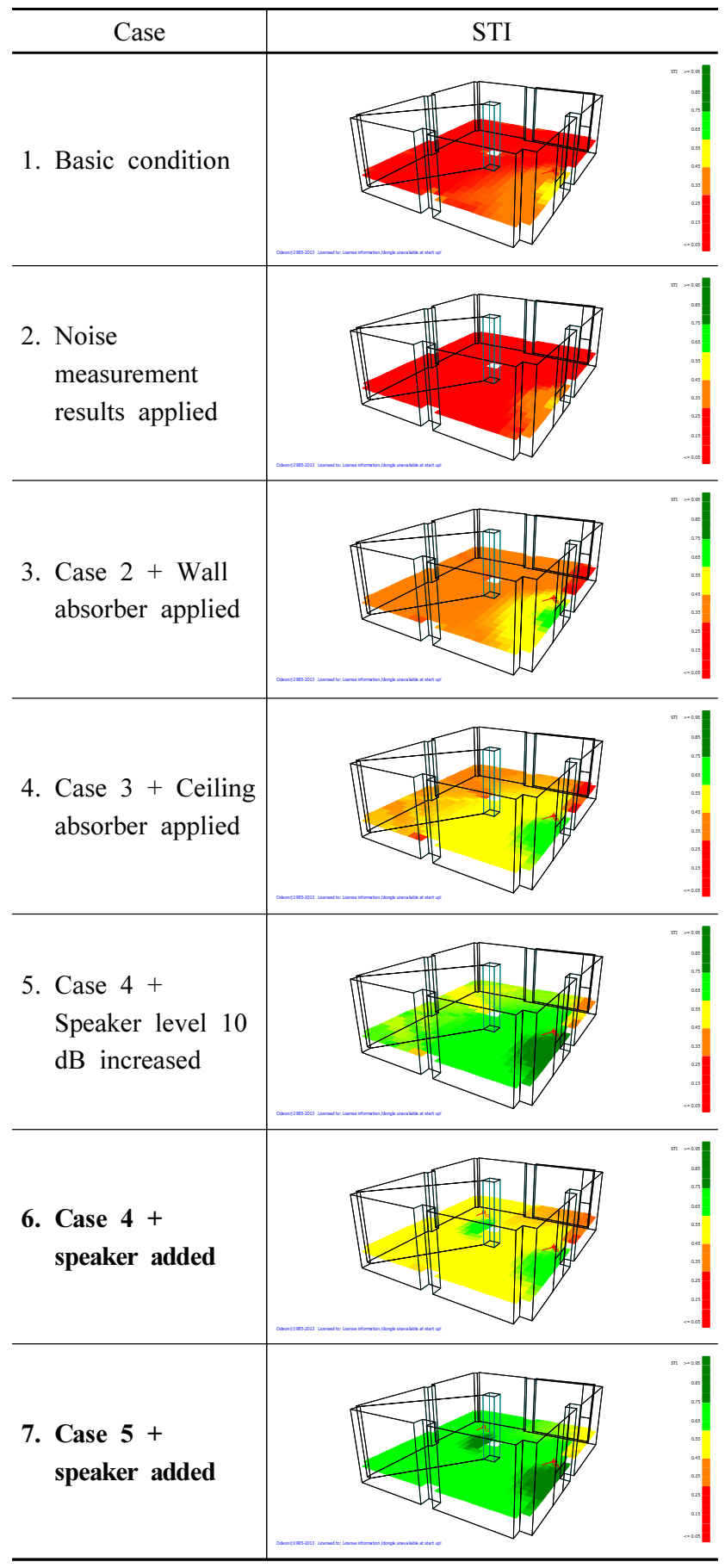

Fig. 7. Averaged STI Values and Ratings in the Electrical Room of the Office Building

을 함께 고려하였을 때 대부분 구역에서 STI가 "Poor"에 해당하는 것으로 나타났다. 흡음재를 적용하였을 때 기계실 과 전기실 전체 구역에서 STI 분포가 개선되었지만, 해당 공간에 설치된 설비에서 발생하는 소음으로 인해 NFPA 72 의 0.50 이상을 만족하기에는 한계가 있는 것으로 나타났 다. 또한, 전기실의 경우 상대적으로 공간의 크기가 작고 스피커가 출입구 상부에 설치되어 있어 기둥에 설치된 기계
실보다 전기실 공간 전체에 전달이 잘 되어 흡음재 효과가 상대적으로 크게 나타난 것으로 판단된다.

Fig. 7은 전기실의 조건별 STI 분포 예측 결과를 정리한 것이다. 전기실의 소음 발생을 고려하지 않았을 때 출입구 위쪽에 설치된 스피커에 가까운 곳에서만 STI가 "Fair" 수준 이었다. 전기실에 발생하는 소음을 고려하여 예측한 결과 (Case 2), STI 기준을 만족한 영역이 줄어들었다. 전기실에서 의 소리 울림을 제어하기 위해 흡음재를 벽면에 적용(Case 3)하면 전기실 대부분 공간에서 STI가 "Bad"에서 "Poor" 등급으로 좋아졌다. 천장에 흡음재를 추가로 적용한 결과 (Case 4) 비상방송용 스피커에서 멀리 떨어진 위치 빼고는 STI가 "Fair" 등급으로 좋아졌다. 전기실의 일부 공간의 STI가 "Poor" 등급인 점을 개선하기 위해 스피커의 소리 크기를 $10 \mathrm{~dB}$ 크기 하여 예측(Case 5)한 결과, 전기실 대부분 공간에서 STI 분포가 “Fair"로 나타나 STI 기준을 만족하였 다. 전기실에서 스피커의 소리 크기를 변화하지 않고 스피커 를 한 개 전기실 중앙부 기둥 부근에 적용한 경우(Case 6), 출입구 위쪽에 적용한 스피커에서 멀리 떨어진 부분을 제외 하고는 STI가 "Fair" 수준으로 분포하였다. 스피커의 소리 크기를 $10 \mathrm{~dB}$ 크기하고 추가 스피커를 적용(Case 7)하면 전기실 대부분 공간에서 STI가 "Good" 이상으로 분포하였다.

\section{4. 결 론}

화재 및 재난 발생했을 때 건축물 안의 다양한 설비와 소화 설비 등이 설치된 기계실, 전기실에서는 신속하고 정확 한 대응이 필요하다. 이를 위해서는 기계실과 전기실 내부 종사자는 각종 경보와 비상방송을 명료하게 청취할 수 있도 록 실내 환경을 구현하여야 한다.

본 연구에서는 사무소 건물의 기계실과 전기실에서의 경보 또는 비상방송설비의 명료도를 비교하였다. 기계실과 전기실에서 발생하는 소음을 측정하여 STI 예측에 적용하였 으며, 실제 공간에서 STI를 측정하는 데에 어려움이 있어 음향 시뮬레이션을 활용하여 예측하였다. STI 예측을 위해 측정한 소음 특성을 입력하였으며, STI 개선 방안으로 공간 안에 흡음재를 적용하여 함께 비교하였다. 기본 공간에 대하 여 비교한 결과 기계실과 전기실에서의 소음 발생으로 STI 평균값은 줄어들어 소음으로 인해 경보와 비상방송음을 더 알아듣기 어려워지는 것으로 나타났다. 기계실과 전기실 의 벽면과 천장에 흡음재를 적용한 결과 STI는 공간 전체에 서 개선되었으나 NFPA 72에서 규정하고 있는 0.50 이상으로 향상되지는 않았다.

STI 기준을 만족하기 위해 벽면과 천장의 흡음재 적용을 기본으로 하고 비상방송용 스피커의 소리를 크게 설정하고, 추가적인 스피커를 예측 모델에 적용하여 예측하였다. 스피 커의 소리 크기를 $10 \mathrm{~dB}$ 이상 크게 하고 추가 스피커를 적용한 결과 기계실과 전기실 모두에서 STI 기준을 만족할 
수 있었다. 기계실과 전기실에서 비상방송설비의 성능 기준 을 만족한 설정이 같지는 않았다. 그러나, STI 기준을 만족하 는 적절한 설정은 비상방송설비 STI 예측을 통해 도출할 수 있음을 확인하였다. 전산 서버실과 피난안전구역의 비상 방송음 명료도를 평가한 이전 연구(Jeong, 2019; 2020b)에서 비상방송음이 배경소음보다 약 $15 \mathrm{~dB}$ 이상 비상방소음이 큰 경우 음성명료도가 높게 나타났다. 이처럼 비상방송설비 설치 대상 공간의 모든 위치에서 비상방송음이 배경소음 보다 약 $15 \mathrm{~dB}$ 이상 크게 전달되어야 적절한 음성명료도 확보가 가능한 것으로 판단된다. 또한, 해당 공간에 고르게 비상방송음을 절달하기 위해서는 스피커의 지향성과 출력 등을 고려한 예측을 통해 스피커 설치 개수와 위치는 설정할 수 있다.

본 연구는 음향 시뮬레이션 기법을 기반으로 시행한 것으 로 향후 실제 기계실과 전기실에서의 음성명료도 개선안 적용과 측정, 평가 연구가 지속해서 필요하다. 또한, 음향 시뮬레이션 수행자마다 같은 결과를 도출하기 위한 시뮬레 이션 세부 설정 등에 대한 지침 수립도 필요하다. 또한, 기계실과 전기실과 같이 화재, 재난 대응에 중요한 공간에서 의 STI 성능 확보를 위해서는 저소음 장치 또는 설비를 사용하는 것도 필요하다.

\section{감사의 글}

본 연구는 정부(과학기술정보통신부)의 재원으로 한국연 구재단의연구비지원(NRF-2019R1F1A1061425)에 의해 수 행되었습니다.

\section{References}

BS 8629. (2019). Code of practice for the design, installation, commissioning and maintenance of evacuation alert systems for use by fire and rescue services in buildings containing flats.

EN 12354-6. (2004). Building acoustics - Estimation of acoustic performance of buildings from the performance of elements - Part 6: Sound absorption in enclosed spaces.

IEC 60268-16. (2020). Sound system equipment - Part 16 :

Objective rating of speech intelligibility by speech transmission index.

IEC 60849. (1998). Sound systems for emergency purposes. Jeong, J.H. (2018). Fire alarm sound transmission in apartment unit. Fire Sci Eng, Vol. 32, No. 3, pp. 67-75.

Jeong, J.H. (2019). Prediction and reduction of alarm sound propagated through elevator shaft. Fire Sci Eng, Vol. 33, No. 4, pp. 89-96.

Jeong, J.H. (2020a). Alarm sound propagation characteristics of gas extinguishing system installed in computer server room. J. Korean Soc. Hazard Mitig, Vol. 20, No. 4, pp. 145-152.

Jeong, J.H. (2020b). Prediction and evaluation of emergency broadcasting sound and speech intelligibility for safety zones in high-rise buildings. Fire Sci Eng, Vol. 34, No. 6, pp. 37-46.

Jeong, J.H. (2021). Prediction and reduction of alarm sound propagated through escape stairways. Fire Technology, Vol. 58, pp. 251-279.

Kim, Y.S., Kim, M.A., and Jeong, J.H. (2021). Review of indicators and standards related to sound intelligibility of architectural acoustics and broadcasting system. Journal of Society for Standards, Certification and Safety, Vol. 11, No. 2, pp. 47-61.

NFPA 72. (2016). National fire alarm and signaling code handbook.

NFSC 202. (2017). Fire safety code for emergency broadcasting system.

\begin{tabular}{l|l} 
Received & September 29, 2021 \\
September 29, 2021 \\
Revised & January 20, 2022 \\
\hline Accepted &
\end{tabular}


